\title{
Quantifying Delay Risk Potential of Road Projects during Construction Phase: A Case Study
}

\author{
Devi Anggraini ${ }^{1, *}$, Jati Utomo Dwi Hatmoko ${ }^{1}$, and Mudjiastuti Handajani ${ }^{1}$ \\ ${ }^{1}$ Civil Engineering, Diponegoro University, 50275 Semarang, Indonesia
}

\begin{abstract}
A comprehensive plan is required to anticipate risks in a construction project. In practice, however, anticipated or unanticipated risks may eventually lead to delays in the project completion date. The aim of this research is to quantify the delay risk potential of a road project during the construction phase. A project at Batang-Kendal road has carried out thorough planning for all required aspects. However, in the implementation of a project, there is often the occurrence of irregular events, which act as a case study for this research, from which delays were identified, observations mapped and semi-structured interviews conducted with project stakeholders, i.e., owner, contractors and supervisory consultants. An instrument was developed to assess and quantify the project risks identified using a 1 to 5 Likert scale. The results showed nine types of delay risks and 32 sub risks. The quantification of these risks was classified into four risk levels, i.e., extreme (6.25\%), high (53.13\%), medium (34.37\%) and low (6.25\%). These findings may represent delay risk potentials of typical road projects during the construction phase, from which lessons can be learned. The assessment instrument proposed can also be used for other road projects, which will be beneficial for project stakeholders in anticipating delay risk potentials.
\end{abstract}

\section{Introduction}

Delays in the construction industry are defined in many terms, one of which refers to the progress of construction implementation based on the initial plan of construction. The construction schedule refers to the schedule prepared by the contractor before the construction project begins. Although, the delay does not always end with the delay of the project, most of the time, the delay of this progress leads to project delays. The study of the causes of delay in construction projects is important because the implementation of each construction project will be limited by time, with deadlines for when activities must begin and end (Astina et al., 2012). Project delays are a major cause of project cost swelling. The factors causing project delays during construction include labour availability, contractor financial problems, equipment, weather, incompetent contractors, late owner payments and geographical conditions at the project site (Priyono, 2016).

\footnotetext{
*Corresponding author: devii.anggrainii@gmail.com
} 
The problem of the study can be stated as follows: what are the most dominant factors causing the delay in the implementation of road construction work in Central Java Province? How to map factor causing delays in the construction phase? And how to develop a project assessment instrument with knowledge of potential job delays.

The purpose of this study to analyse the delay risk potential road construction project at Batang-Kendal roadworks in Central Java Province. The purpose of this research is to identify factors causing delays in the construction phase, to map the factors causing delays in the construction phase, to develop an assessment instrument with knowledge of the potential job delays and to analyse the response to be taken from factors causing delays in the construction phase.

\section{Literature Review}

The identification of factors that may cause project delays begins with a literature review. The factors causing the delays that act as a reference for this study are as follows:

Table 1. Sub-factor causing delays in construction phase.

\begin{tabular}{|c|c|c|c|}
\hline No. & $\begin{array}{c}\text { Factors causing } \\
\text { delays }\end{array}$ & Sub-factors causing delays & References \\
\hline \multirow{6}{*}{1} & \multirow[t]{6}{*}{ Labour factor } & Lack of labour factor & [5] \\
\hline & & Low labour productivity & [8] \\
\hline & & Workplace accidents & [8] \\
\hline & & Resource mobilisation is slow & {$[8]$} \\
\hline & & Limitations of the use of technology & {$[10]$} \\
\hline & & Understanding of the methods of work & {$[1]$} \\
\hline \multirow{4}{*}{2} & \multirow[t]{4}{*}{ Material factor } & Availability of certain materials in the market & {$[5,6]$} \\
\hline & & Delay of material delivery to location & {$[8]$} \\
\hline & & Quality of materials does not meet specifications & {$[2,7]$} \\
\hline & & Rising market prices & {$[2,7]$} \\
\hline \multirow{4}{*}{3} & \multirow[t]{4}{*}{ Equipment factor } & Lack of equipment in the field & {$[3,5,6]$} \\
\hline & & Delay in delivery/supply of equipment & {$[10]$} \\
\hline & & Productivity of equipment & {$[5]$} \\
\hline & & Ability to operate equipment & {$[8]$} \\
\hline \multirow{3}{*}{4} & \multirow[t]{3}{*}{ Financial factor } & Payment of work is late & {$[3,5,6]$} \\
\hline & & Cost swelling & {$[8]$} \\
\hline & & Contractor's financial ability & {$[3,5,6]$} \\
\hline \multirow[b]{2}{*}{5} & \multirow{2}{*}{$\begin{array}{l}\text { Environment } \\
\text { factor }\end{array}$} & Rainfall intensity & {$[10]$} \\
\hline & & $\begin{array}{l}\text { Occurrence of unexpected events like fire, flooding } \\
\text { and landslides }\end{array}$ & [3] \\
\hline 6 & $\begin{array}{l}\text { Scope factor and } \\
\text { contract }\end{array}$ & Additional work required & {$[3,5,6,7]$} \\
\hline \multirow{4}{*}{7} & \multirow{4}{*}{$\begin{array}{l}\text { Control system } \\
\text { factor and work } \\
\text { evaluation }\end{array}$} & Accuracy of construction methods & {$[6,7]$} \\
\hline & & Supervision is not optimal & {$[10]$} \\
\hline & & Completeness of the contract addendum & {$[10]$} \\
\hline & & No test case is performed & {$[8]$} \\
\hline \multirow{2}{*}{8} & \multirow[t]{2}{*}{ Managerial factors } & Contractor experience & [6] \\
\hline & & Contractor productivity is not optimum & {$[5]$} \\
\hline
\end{tabular}




\begin{tabular}{|c|l|l|l|}
\hline No. & $\begin{array}{c}\text { Factors causing } \\
\text { delays }\end{array}$ & \multicolumn{1}{|c|}{ Sub-factors causing delays } & References \\
\hline \multirow{2}{*}{9} & & Slow decision making & {$[8]$} \\
\cline { 3 - 4 } & & Poor management on the field & {$[6,7]$} \\
\hline \multirow{3}{*}{$\begin{array}{l}\text { Supervision } \\
\text { factors }\end{array}$} & Lack of supervision of sub-contractors and suppliers & {$[8]$} \\
\cline { 3 - 4 } & Lack of adequate information from the consultant & {$[9]$} \\
\cline { 3 - 4 } & $\begin{array}{l}\text { Weaknesses in supervision by owner, field supervisors } \\
\text { and supervisory consultants }\end{array}$ & {$[2]$} \\
\cline { 3 - 4 } & Ratio of supervisors and number of packages & {$[8]$} \\
\hline
\end{tabular}

\section{Research Methodology}

The focus of this research is a road construction project in Central Java Province at the Batang-Kendal roadworks (STA $59+500 \mathrm{~s} / \mathrm{d} 61+300$ ). In the study, interviews were conducted systematically based on the sequence of interview guides that was prepared before the interview.

A questionnaire was used as an instrument to measure the conditions occurring in each project (condition value) that is given to three stakeholders, they are owners, contractors and supervisors. The questions on each questionnaire are adjusted to stakeholders that are affected by delay factors.

The analysis is divided into three stages:

1. Factors causing delays are analysed using the risk breakdown structure. Grouping the factors causing delays based on the root of the problem or based on categories that are considered important can help improve the effectiveness of the prevention of the cause of the delay.

2. In subsequent stages, for the sub-factor causing the delay, the condition criteria are mapped that describe the sub-factor causing the delay in a condition, in this case, it is called the condition value. Briefly, it can be interpreted as an observation object in the form of sub-factors that have variations in value. The lowest value is 1 (according to ideal conditions) and the highest value is 5 (this is not in accordance with ideal conditions).

3. The average result of filling by each stakeholder (owner, contractor and supervisor) is used to obtain the value of the project delay zone. In this case, the delay zone is mapped to four zones: red, orange. yellow, and green. The zone system of the potential road project delays is shown in Table 2 .

Table 2. Project delay level.

\begin{tabular}{|l|l|l|}
\hline \multicolumn{1}{|c|}{ Zone } & \multicolumn{1}{|c|}{ Score } & \multicolumn{1}{c|}{ Description } \\
\hline Extreme/red & $3.76-5.00$ & $\begin{array}{l}\text { Delay time of 10-20\%, with a huge impact } \\
\text { that requires particular handling. }\end{array}$ \\
\hline High/orange & $2.51-3.75$ & $\begin{array}{l}\text { Delay time of 5-10\%, with a medium impact } \\
\text { that needs to be handled periodically. }\end{array}$ \\
\hline Medium/yellow & $1.26-2.5$ & $\begin{array}{l}\text { Delay time of }<5 \%, \text { with a little impact that } \\
\text { needs attention to the project schedule. }\end{array}$ \\
\hline Low/green & $0-1.25$ & $\begin{array}{l}\text { Minute delay time that does not affect the } \\
\text { schedule. }\end{array}$ \\
\hline
\end{tabular}




\section{Results and Discussion}

\subsection{Identification and Classification}

For the analysis in the construction phase, there are 32 sub-variables that are analysed, based on the results of the questionnaire.

Table 3. Results of calculation of delay construction in package (Batang-Kendal Road).

\begin{tabular}{|c|c|c|c|c|c|c|c|c|}
\hline \multirow[b]{2}{*}{ No } & \multirow[b]{2}{*}{$\begin{array}{l}\text { Factors } \\
\text { causing } \\
\text { delays }\end{array}$} & \multirow[b]{2}{*}{ No } & \multirow[b]{2}{*}{$\begin{array}{c}\text { Sub factors causing } \\
\text { delays }\end{array}$} & \multicolumn{3}{|c|}{$\begin{array}{l}\text { Condition of } \\
\text { value }\end{array}$} & \multirow{2}{*}{ 兽 } & \multirow[b]{2}{*}{$\begin{array}{c}\text { Value of } \\
\text { project } \\
\text { delay } \\
\text { zone }\end{array}$} \\
\hline & & & & 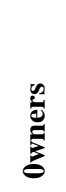 & 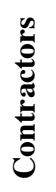 & : & & \\
\hline \multirow[t]{6}{*}{1} & \multirow[t]{6}{*}{$\begin{array}{l}\text { Labour } \\
\text { factor }\end{array}$} & 1.1 & $\begin{array}{l}\text { Lack of labour factor } \\
\text { (X1) }\end{array}$ & & 2 & 3 & 2.5 & Medium \\
\hline & & 1.2 & $\begin{array}{l}\text { Low labour } \\
\text { productivity (X2) }\end{array}$ & & 3 & 3 & 3 & High \\
\hline & & 1.3 & $\begin{array}{l}\text { Workplace accidents } \\
\text { (X3) }\end{array}$ & & 1 & 1 & 1 & Low \\
\hline & & 1.4 & $\begin{array}{l}\text { Resource mobilisation } \\
\text { is slow (X4) }\end{array}$ & & 3 & 4 & 3.5 & High \\
\hline & & 1.5 & $\begin{array}{l}\text { Limitations of the use } \\
\text { of technology (X5) }\end{array}$ & & 2 & 2 & 2 & Medium \\
\hline & & 1.6 & $\begin{array}{l}\text { Understanding of } \\
\text { methods of work (X6) }\end{array}$ & & 3 & & 3 & High \\
\hline \multirow[t]{4}{*}{2} & \multirow[t]{4}{*}{$\begin{array}{l}\text { Material } \\
\text { factor }\end{array}$} & 2.1 & $\begin{array}{l}\text { Availability of certain } \\
\text { materials in the market } \\
\text { (X7) }\end{array}$ & & 3 & & 3 & High \\
\hline & & 2.2 & $\begin{array}{l}\text { Delay of material } \\
\text { delivery to location } \\
\text { (X8) }\end{array}$ & & 3 & & 3 & High \\
\hline & & 2.3 & $\begin{array}{l}\text { Quality of materials } \\
\text { does not meet } \\
\text { specifications (X9) }\end{array}$ & & 3 & 4 & 3.5 & High \\
\hline & & 2.4 & $\begin{array}{l}\text { Rise in market prices } \\
(\mathrm{X} 10)\end{array}$ & & 2 & 2 & 2 & Medium \\
\hline \multirow[t]{4}{*}{3} & \multirow[t]{4}{*}{$\begin{array}{l}\text { Equipment } \\
\text { factor }\end{array}$} & 3.1 & $\begin{array}{l}\text { Lack of equipment in } \\
\text { the field (X11) }\end{array}$ & & 3 & 3 & 3 & High \\
\hline & & 3.2 & $\begin{array}{l}\text { Delay in } \\
\text { delivery/supply of } \\
\text { equipment (X12) }\end{array}$ & & 4 & 5 & 4.5 & Extreme \\
\hline & & 3.3 & $\begin{array}{l}\text { Productivity of } \\
\text { equipment (X13) }\end{array}$ & & 3 & & 3 & High \\
\hline & & 3.4 & $\begin{array}{l}\text { Ability to operate } \\
\text { equipment (X14) }\end{array}$ & & 2 & & 2 & Medium \\
\hline \multirow[t]{3}{*}{4} & \multirow[t]{3}{*}{$\begin{array}{l}\text { Financial } \\
\text { factor }\end{array}$} & 4.1 & $\begin{array}{l}\text { Payment of work is } \\
\text { late (X15) }\end{array}$ & & 2 & & 2 & Medium \\
\hline & & 4.2 & $\begin{array}{l}\text { There is a cost } \\
\text { swelling (X16) }\end{array}$ & & 3 & & 3 & High \\
\hline & & 4.3 & $\begin{array}{l}\text { Contractor's financial } \\
\text { ability (X17) }\end{array}$ & & 3 & & 3 & High \\
\hline
\end{tabular}




\begin{tabular}{|c|c|c|c|c|c|c|c|c|}
\hline \multirow[b]{2}{*}{ No } & \multirow[b]{2}{*}{$\begin{array}{l}\text { Factors } \\
\text { causing } \\
\text { delays }\end{array}$} & \multirow[b]{2}{*}{ No } & \multirow[b]{2}{*}{$\begin{array}{c}\text { Sub factors causing } \\
\text { delays }\end{array}$} & \multicolumn{3}{|c|}{$\begin{array}{l}\text { Condition of } \\
\text { value }\end{array}$} & \multirow{2}{*}{ 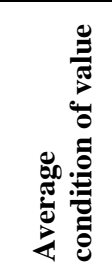 } & \multirow[b]{2}{*}{$\begin{array}{c}\text { Value of } \\
\text { project } \\
\text { delay } \\
\text { zone }\end{array}$} \\
\hline & & & & 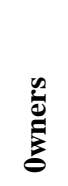 & 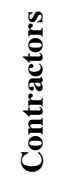 & 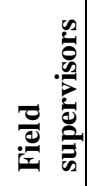 & & \\
\hline \multirow[t]{2}{*}{5} & \multirow[t]{2}{*}{$\begin{array}{l}\text { Environmen } \\
\mathrm{t} \text { factor }\end{array}$} & 5.1 & $\begin{array}{l}\text { Rainfall intensity } \\
\text { (X18) }\end{array}$ & 3 & 3 & & 3 & High \\
\hline & & 5.2 & $\begin{array}{l}\text { Occurrence of } \\
\text { unexpected things like } \\
\text { fire, flood, landslide } \\
\text { (X19) }\end{array}$ & 2 & 2 & & 2 & Medium \\
\hline 6 & $\begin{array}{l}\text { Scope factor } \\
\text { and contract }\end{array}$ & 6.1 & $\begin{array}{l}\text { Additional work } \\
\text { required (X20) }\end{array}$ & 5 & 5 & & 5 & Extreme \\
\hline \multirow[t]{4}{*}{7} & \multirow{4}{*}{$\begin{array}{l}\text { Control } \\
\text { system } \\
\text { factor and } \\
\text { work } \\
\text { evaluation }\end{array}$} & 7.1 & $\begin{array}{l}\text { Accuracy of } \\
\text { construction } \\
\text { methods(X21) }\end{array}$ & 4 & 3 & 4 & 3.67 & High \\
\hline & & 7.2 & $\begin{array}{l}\text { Supervision is not } \\
\text { optimal (X22) }\end{array}$ & 2 & 2 & 2 & 2 & Medium \\
\hline & & 7.3 & $\begin{array}{l}\text { Completeness of the } \\
\text { contract addendum } \\
\text { (X23) }\end{array}$ & 4 & 3 & 3 & 3.33 & High \\
\hline & & 7.4 & $\begin{array}{l}\text { No test case is } \\
\text { performed (X24) }\end{array}$ & 3 & 3 & 3 & 3 & High \\
\hline \multirow[t]{4}{*}{8} & \multirow[t]{4}{*}{$\begin{array}{l}\text { Managerial } \\
\text { factors }\end{array}$} & 8.1 & $\begin{array}{l}\text { Contractor experience } \\
\text { (X25) }\end{array}$ & 2 & 2 & & 2 & Medium \\
\hline & & 8.2 & $\begin{array}{l}\text { Contractor } \\
\text { productivity is not } \\
\text { optimum (X26) }\end{array}$ & 2 & 2 & & 2 & Medium \\
\hline & & 8.3 & $\begin{array}{l}\text { Slow decision making } \\
\text { (X27) }\end{array}$ & 4 & 3 & & 3.5 & High \\
\hline & & 8.4 & $\begin{array}{l}\text { Poor management on } \\
\text { the field (X28) }\end{array}$ & 3 & 3 & 3 & 3 & High \\
\hline \multirow[t]{4}{*}{9} & \multirow[t]{4}{*}{$\begin{array}{l}\text { Supervision } \\
\text { factors }\end{array}$} & 9.1 & $\begin{array}{l}\text { Lack of supervision of } \\
\text { sub-contractors and } \\
\text { suppliers (X29) }\end{array}$ & & & 3 & 3 & High \\
\hline & & 9.2 & $\begin{array}{l}\text { Lack of adequate } \\
\text { information from the } \\
\text { consultant (X30) }\end{array}$ & & & 2 & 2 & Medium \\
\hline & & 9.3 & $\begin{array}{l}\text { Weaknesses in } \\
\text { supervision by owner, } \\
\text { field supervisors, and } \\
\text { supervisory } \\
\text { consultants (X31) }\end{array}$ & & & 2 & 2 & Medium \\
\hline & & 9.4 & $\begin{array}{l}\text { Ratio of supervisors } \\
\text { and the number of } \\
\text { packages (X32) }\end{array}$ & & & 2 & 2 & Low \\
\hline \multicolumn{7}{|c|}{ e delay of valu } & 2.77 & High \\
\hline
\end{tabular}

From Table 3, there are two factors that are at the extreme level $(6.25 \%), 17$ factors are at the high level $(53.13 \%), 11$ factors are at the medium level $(34.38 \%)$ and two factors are at the low level (6.25\%). Sub-factors causing delays at extreme and high levels needs to be mapped out the solution so that the progress toward the completion of the project is achieved and punctual. Mapping of the sub-factors causing delays is shown in Figs. 1 and 2. 


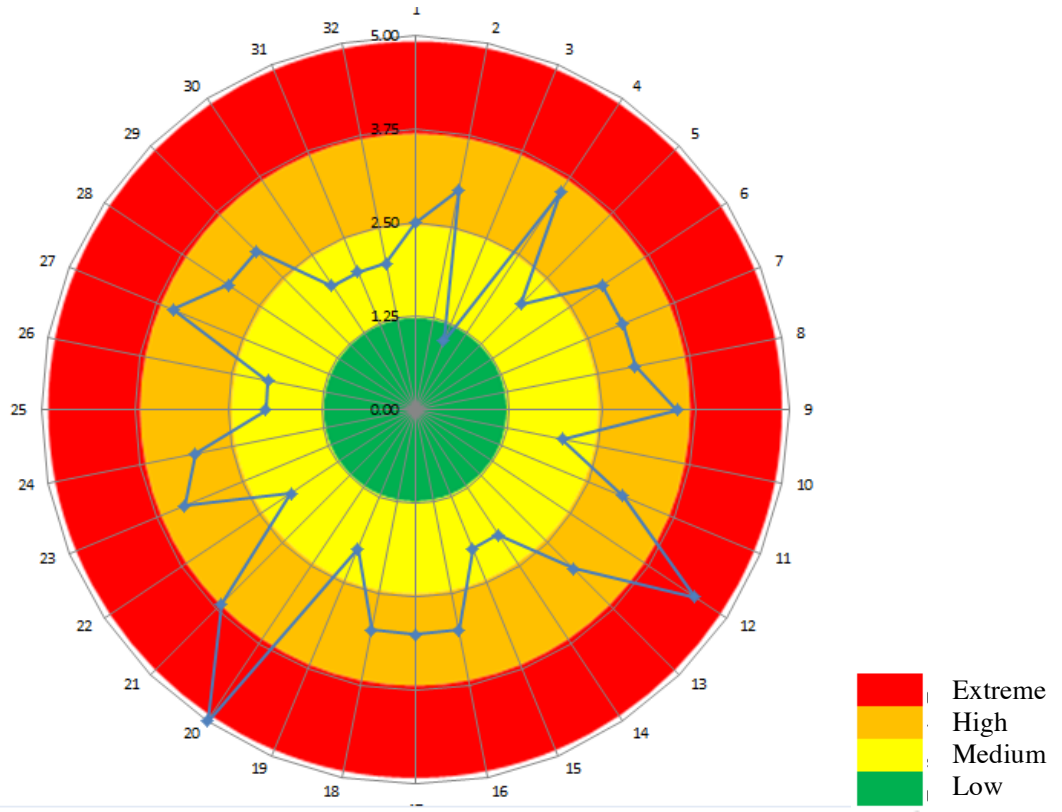

Fig. 1. Mapping of sub-factors causing delays.

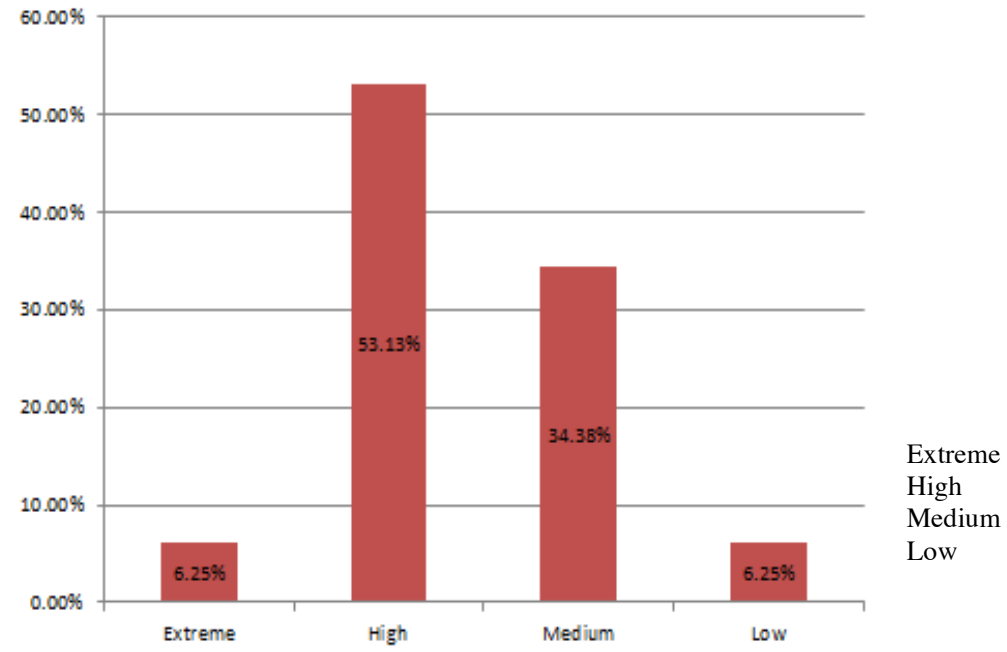

Fig. 2. Classification of project delay level.

Based on the assessment results of the average delay in the Batang-Kendal Road project, the construction phase has a cumulative score of 2.77 , which is at a high level. This indicates that at the stage of a project has activities that affect each other to go to the next stage. Thus, if in the early stages, it has experienced delays, it will affect the delay in the next stage of work. Therefore, it is necessary to map the cause of the delay at the beginning of the project along with the response of the handling, so that the delay does not accumulate at the next work stage. 


\subsection{Risk Analysis}

Based on the analysis and assessment results, the following explanations can be proposed:

1. Significant work added.

The changes in the scope during the implementation due to the lack of planning results with real conditions in the field. In this case, the addition of the concrete volume for rigid pavement work.

2. Delivery delay/equipment supply

The delay that occurs is during rigid pavement work. The limitation of equipment during the execution of work resulted in late work. In this case, the owner of the appliance asks for a cash payment.

3. Slow decision making

The changes that are not immediately carried out because they have to wait for the decision that has been approved. In this case, waiting for the result of the amendment change of volume, as set forth in the amendment.

4. No test case is performed

In this case, during the plan progress if 54\%, the deviation of $10 \%$ so that it is conducted SCM I (Show Cause Meeting I), which is done the agreement to achieve progress determined in accordance with agreed time. For SCM I, contractors successfully achieve the predetermined progress.

5. Weaknesses in supervision by owner, field supervisors and supervisory consultants Contractor parties do not coordinate with the field supervisor when they want to carry out the work, so the supervision on the implementation of the work is not run optimally. The role of supervision is necessary to monitor the performance of the work and to provide corrections of the work carried out by the contractor, it is in order to conform to the mutually agreed contract of work.

6. Material quality is not in accordance with specifications

The scarcity of obtaining quality rock material (split) causes the supply of split material for the concrete mix becomes late. Therefore, the implementation is delayed. To overcome these problems, then it should be obtained the material needed as much as possible by looking for alternative material providers as much as possible.

7. Lack of supervision of sub-contractors and suppliers

The contractor/subcontractor does not coordinate with the field supervisor when they want to carry out the work, so the supervision on the implementation of the work does not run optimally. The role of supervision is necessary to monitor the performance of the work and to provide corrections of the work carried out by the contractor in order to conform to the mutually agreed contract of work. The solution to overcome this is for the contractor must notify the supervisor in writing, when he/she will carry out the work.

8. Understanding of working methods

The understanding of the method of work is limited to the foreman, so that during the implementation in the field, there is a misunderstanding of the providers of instructions on the rules of implementation of work. The solution to overcome this is by doing a briefing before starting the work.

9. Low productivity of labour

The contractors do too much work at the same time, while the financial conditions are not supportive because it is broken down to finance other projects. This makes the late payment of labour wages. Therefore, the labour force is less enthusiastic in work, which impacts on decreased work productivity. The solution to overcome this is that the contractor should not be late to give workers' wages. 


\subsection{Risk Response}

For every risk occurring in the field, stakeholders have a role in responding to those risks. The stakeholders perspective responses in the phase construction are shown in Table 3 . In this case, responses are based on the level of project delay (extreme and high).

Table 4. Risk response of sub-factors causing delays.

\begin{tabular}{|c|c|c|}
\hline Sub-factors causing delays & $\begin{array}{c}\text { Level of } \\
\text { project } \\
\text { delay }\end{array}$ & Risk response \\
\hline Low labour productivity (X2) & High & $\begin{array}{l}\text { Increased ability of labour with training, } \\
\text { give rewards }\end{array}$ \\
\hline Resource mobilisation is slow (X4) & High & $\begin{array}{l}\text { Check schedule of labour, materials and } \\
\text { equipment }\end{array}$ \\
\hline $\begin{array}{l}\text { Understanding of methods of work } \\
\text { (X6) }\end{array}$ & High & Briefing before starting the work \\
\hline $\begin{array}{l}\text { Availability of certain materials in the } \\
\text { market (X7) }\end{array}$ & High & $\begin{array}{l}\text { Coordinate with supplier that has material } \\
\text { availability }\end{array}$ \\
\hline $\begin{array}{l}\text { Delay of material delivery to location } \\
(\mathrm{X} 8)\end{array}$ & High & $\begin{array}{l}\text { Coordinate with supplier and must have } \\
\text { responsible supplier }\end{array}$ \\
\hline $\begin{array}{l}\text { Quality of materials does not meet } \\
\text { specifications (X9) }\end{array}$ & High & $\begin{array}{l}\text { Test of material quality and field } \\
\text { supervisors are entitled to reject poor } \\
\text { materials }\end{array}$ \\
\hline Lack of equipment in the field (X11) & High & $\begin{array}{l}\text { Coordinate with provider and seeking other } \\
\text { equipment providers }\end{array}$ \\
\hline $\begin{array}{l}\text { Delay in delivery/supply of equipment } \\
\text { (X12) }\end{array}$ & Extreme & $\begin{array}{l}\text { Equipment leases must be made in advance } \\
\text { and payments are made in cash }\end{array}$ \\
\hline Productivity of equipment (X13) & High & $\begin{array}{l}\text { Adding the equipment as required in the } \\
\text { technical specification }\end{array}$ \\
\hline Cost swelling (X16) & High & $\begin{array}{l}\text { Check labour and equipment schedule, } \\
\text { optimise labour productivity and tools }\end{array}$ \\
\hline Contractor's financial ability (X17) & High & $\begin{array}{l}\text { Financial management must be well } \\
\text { managed for good cash flow }\end{array}$ \\
\hline Rainfall intensity (X18) & High & $\begin{array}{l}\text { Work schedule modification and adding } \\
\text { overtime, tools and labour }\end{array}$ \\
\hline Significant work added (X20) & Extreme & $\begin{array}{l}\text { Re-calculate costs incurred as a result of } \\
\text { work added, realistic schedule, availability } \\
\text { material and labour }\end{array}$ \\
\hline $\begin{array}{l}\text { Accuracy of construction methods } \\
\text { (X21) }\end{array}$ & High & $\begin{array}{l}\text { Contractor must obey with the rules, } \\
\text { method at the legal contract and coordinate } \\
\text { with field supervisor }\end{array}$ \\
\hline $\begin{array}{l}\text { Completeness of contract addendum } \\
\text { (X23) }\end{array}$ & High & $\begin{array}{l}\text { Coordinate all of stakeholder for } \\
\text { completeness back up and to be guidance }\end{array}$ \\
\hline No test case is performed (X24) & High & $\begin{array}{l}\text { Determine the progress of the plan to be } \\
\text { achieved within a certain time and } \\
\text { evaluated }\end{array}$ \\
\hline Slow decision making (X27) & High & $\begin{array}{l}\text { Coordinate all of stakeholder to result for } \\
\text { the decision that has been approved }\end{array}$ \\
\hline Poor management on the field (X28) & High & $\begin{array}{l}\text { Personnel must be capable with their desk } \\
\text { job }\end{array}$ \\
\hline $\begin{array}{l}\text { Lack of supervision of sub-contractors } \\
\text { and suppliers (X29) }\end{array}$ & High & $\begin{array}{l}\text { Contractor must notify the supervisor in } \\
\text { writing when he/she will carry out the } \\
\text { work. }\end{array}$ \\
\hline
\end{tabular}




\section{Conclusions}

The construction project at Batang-Kendal road has 32 risks to identify in phase construction. The mapping of sub-factors causing delays obtained, there are two factors that are at the extreme level $(6.25 \%), 17$ factors at the high level $(53.13 \%), 11$ factors at the medium level $(34.38 \%)$ and two factors at the low level $(6.25 \%)$. The main cause of the delay is the added work and delay in delivery of equipment. Meanwhile, overall the project is included in the high level with a value of 2.77. The sequence of a project has activities that affect each other to go to the next stage. Thus, if in the early sequences it has experienced delays, it will affect the delay in the next stage of work.

\section{References}

1. Aibinu A. and Jagboro G. O., The Effects of Construction Delay on Project Delivery in Nigerian Construction Industry, International Journal of Project Management, 25, pp. 593-599 (2002).

2. Alinaitwe H., Apolot R. and Tindiwensi D., Investigation into the causes of Delays and Cost Overruns in Uganda's Public Sector Construction Projects, Journal of Construction in Developing Countries, 18(2), pp. 33-47 (2013).

3. Ayudhya B. I. N., Evaluation of Common Delay Causes of Construction Projects in Singapore. Journal Of Civil Engineering and Architecture (2011)

4. Gandhak P. S. and Sabihuddin S., Stakeholders' perception of the causes and effect of construction delays on project delivery, International Journal of Modern Engineering Research (IJMER), 14(2), 153-161 (2014).

5. M.J. Kamanga dan W.J.v.d.M Steyn., Causes of delay in road construction projects in Malawi. Journal of the south African Institution of Civil Engineering, Vol.55 (3), pp. 7985. (2013)

6. Mahamid I .Common risks affecting time overrun in road construction projects in Palestine: Contractor's perspective, Australasian Journal of Construction Economics and Building, 13 (2), pp.45-53. (2013)

7. Patil, S.K., Gupta A.K., Desai D.B dan Sajane., Causes of Delay in Indian Transportation Infrastructure Projects. International Journal of Research in Engineering and Technology. (2013).

8. Priyono, Hery., Analisa Keterlambatan Proyek Konstruksi di Kabupaten Rembang.Tesis. Universitas Diponegoro Semarang. (2016)

9. Sambasivan, M. dan Y. W. Soon. Cwasan causes and Effects of Delays in Malaysian Construction Industry. International Journal of Project Management. Elsevier. (2006)

10. Suyatno. Analisis Faktor Penyebab Keterlambatan Penyelesaiaan Proyek Gedung. Tesis. Universitas Diponegoro, Semarang. (2010) 